\title{
Armin Lange \\ Jew-Hatred in Antiquity: Cultural, Legal, and Physical Forms of Antisemitic Persecution
}

Jew-hatred in antiquity and late antiquity has been subject to several studies with varying degrees of scholarly quality and widely differing appreciations of the extent and character of the rejection and persecution of Jews in these periods. ${ }^{1}$ Furthermore, Jew-hatred in antiquity and late antiquity has been surveyed in albeit mostly brief chapters in various overall histories of antisemitism. ${ }^{2} \mathrm{Al}$ though ancient and late ancient Jew-hatred is not in the center of most of antisemitism studies, ${ }^{3}$ there is ample scholarly literature engaging with the phe-

1 The following are just a few examples for studies of high scholarly quality: A. Cuffari, Judenfeindschaft in Antike und Altem Testament: Terminologische, Historische und Theologische Untersuchungen (Hamburg: Philo, 2007); J. G. Gager, The Origins of Anti-Semitism: Attitudes Toward Judaism in Pagan and Christian Antiquity (New York: Oxford University Press, 1985); V. Herholt, Antisemitismus in der Antike: Kontinuitäten und Brüche eines historischen Phänomens (Gutenberg: Computus, 2009); B. Isaac, The Invention of Racism in Classical Antiquity (Princeton: Princeton University Press, 2013); K. L. Noethlichs, Die Juden im christlichen Imperium Romanum (4.6. Jahrhundert) (Berlin: Akademie-Verlag, 2001); P. Schäfer, Judeophobia: Attitudes toward the Jews in the Ancient World (Cambridge: Harvard University Press, 1997); M. Simon, Verus Israel: A Study of the Relations between Christians and Jews in the Roman Empire (AD 135-425), trans. H. McKeating (Oxford: Oxford University Press, 1986); C.-P. Thiede and Stingelin, Die Wurzeln des Antisemitismus: Judenfeindschaft in der Antike, im frühen Christentum und im Koran (Basel: Brunnen-Verlag, 2002); Z. Yavetz, Judenfeindschaft in der Antike: Die Münchener Vorträge (München: Beck, 1997).

2 Cf. e.g. D. Berger, History and Hate: The Dimensions of Anti-Semitism (Philadelphia: Jewish Publication Society, 1997); T. B. Eriksen et al., Judenhass: Die Geschichte des Antisemitismus von der Antike bis zur Gegenwart (Göttingen: Vandenhoeck \& Ruprecht, 2019); W. Laquer, The Changing Face of Anti-Semitism: From Ancient Times to the Present Day (Cary: Oxford University Press, 2006); M. Perry and F. M. Schweitzer, Antisemitism: Myth and Hate from Antiquity to the Present (Basingstoke: Palgrave McMillan, 2005); L. Poliakov, The History of Anti-Semitism, 4 vols. (Philadelphia: University of Pennsylvania Press, 2003); H. Schreckenberg, Die christlichen Adversus-Judaeos-Texte und ihr literarisches und historisches Umfeld, 3 vols. (Frankfurt/Main: Peter Lang, 1982-1994); R. Wistrich, Antisemitism: The Longest Hatred (New York: Pantheon, 1992); R. Wistrich, A Lethal Obsession: Anti-Semitism from Antiquity to the Global Jihad (New York: Random House, 2010).

3 An indicator of the marginalization of ancient Jew-hatred is the Handbuch des Antisemtismus, ed. W. Benz (Berlin: De Gruyter, 2010) which does not engage with either epoch on a comprehensive level.

Ә OpenAccess. (C) 2021 Armin Lange, published by De Gruyter. (cc) BY-NC-ND This work is licensed under the Creative Commons Attribution-NonCommercial-NoDerivatives 4.0 International License.

https://doi.org/10.1515/9783110671995-004 
nomenon. Scholars differ significantly in the appreciation of ancient Jew-hatred. Some claim that it was at best a marginal phenomenon and that antisemitism did not exist in (late) antiquity. ${ }^{4}$ Others argue that Jew-hatred was an important aspect that determined the relationship of both the pagan and Christian worlds with Judaism. ${ }^{5}$

Given these diverse appreciations of and attitudes to ancient Jew-hatred in scholarly literature, it might be appropriate to survey the history of persecution of Judaism in antiquity. Such a survey might be able to provide answers as to whether antisemitism existed in antiquity and how marginal or mainstream it was in ancient societies and cultures. The answer to both questions depends significantly on how antisemitism is defined and how antiquity is delineated. Next to such terminological clarity, a survey of antisemitism in antiquity also has to ask which principal forms of the persecution of Jews existed in this period.

\section{What is Antisemitism and What is Antiquity?}

If the term antisemitism is defined as a description of exclusively modern (racist) Jew-hatred, ${ }^{6}$ no antisemitism could have existed in either antiquity or late antiquity. If antisemitism is understood as a hatred, the modern and contemporary expressions of which are just the latest form of an age-old phenomenon, then (late) ancient Jew-hatred could very well have been an expression of antisemitism. If late antiquity ends with the collapse of the Western Roman Empire in 476 C.E. or with the end of the reign of Justinian in 565 C.E., the racial characteristics of Visigothic legislation against the Jews of Spain becomes part of the Middle Ages, and those who define antisemitism as purely racist could argue that an-

4 See for instance the article by E. Gruen, "The Blood Libel and the Leper Libel: Ancient Antisemitism?” in the present volume, or B. Bar-Kochva's The Image of the Jews in Greek Literature: The Hellenistic Period (Berkeley: University of California Press, 2010). Cf. also Isaac, Invention of Racism.

5 Cf. e.g. Yavetz, Judenfeindschaft, or Simon, Verus Israel.

6 Cf. e.g. W. Bergmann, Geschichte des Antisemitismus (München: C.H. Beck, 2002); C. Guillaumin, L’idéologie raciste: Genèse et langage actuel (Paris: Gallimard, 1972); J. Heil, “'Antijudaismus' und 'Antisemitismus': Begriffe als Bedeutungsträger,” Jahrbuch für Antisemitismusforschung 6 (1997): 92-114; G. I. Langmuir, Toward a Definition of Antisemitism (Berkeley: University of California Press, 1990); T. Nipperdey and R. Rürup, “Antisemitismus,” in Geschichtliche Grundbegriffe: Historisches Lexikon zur politisch-sozialen Sprache in Deutschland, ed. O. Brunner, W. Conze, and R. Koselleck (Stuttgart: Klett-Cotta, 1972), 129-53. 
tisemitism began only in Medieval times. ${ }^{7}$ If, however, the Arab conquest of the seventh and eighth centuries C.E. marks the end of late antiquity, the Visigothic antisemitic legislation would be part of late antiquity.

The above examples show that definitions of antisemitism and the delineation of the periods of antiquity and late antiquity impact the question of whether antisemitism existed in either one of these periods significantly. It is therefore important to explain how I delimit antiquity on the one hand, and how I define antisemitism on the other hand.

A common delineation of antiquity is to set its beginnings ca. 800 B.C.E. and its end with the end of the Arab conquest of much of the Roman world in the seventh and eighth centuries C.E. ${ }^{8}$ Inside this time window of more ca. 1500 years, it is now common to distinguish between antiquity and late antiquity. The beginning of late antiquity is often identified as the reign of Emperor Diocletian (284-305 C.E.). However, for the history of Judaism, the so-called Constantinian shift in the year 313 C.E. was a much more incisive event. It was in this year, that by way of the edict of Milan, Emperors Constantine (ruled 306-337 C.E.) and Licinius (ruled 308-324 C.E.) paved the way for Christianity to become the state religion of the Roman world in the 380 C.E. In my opinion, the end of late antiquity is marked by the Arab conquest of the Spanish Visigothic kingdom during the years 711725 C.E. At the latest at this point, the Roman Empire was reduced to a regional power in Eastern Mediterranean with the Frankish and Langobard kingdoms as the only surviving Germanic successor states.

Focusing on antiquity, my present survey addresses thus the ancient period until its end with the reign of Diocletian and the so-called Constantinian shift in 313 C.E. but not late antiquity. There can be no doubt that during this time Jews suffered from various forms of discrimination and persecution and that they were subject to cultural and religious ridicule. Is it appropriate though to describe these ancient expressions of Jew-hatred as antisemitism?

As I have argued above, the answer to this question depends heavily on how antisemitism is defined. However, to the question "What is Antisemitism?" as many answers are given as there were and are researchers asking it. The present article is clearly not the place for an extensive discussion of this issue. However, a few brief remarks are in order.

7 See e.g. R. Chazan, Medieval Stereotypes and Modern Antisemitism (Berkeley: University of California Press, 1997), Langmuir, Toward a Definition of Antisemitism; R. I. Moore, The Formation of a Persecuting Society: Power and Deviance in Western Europe, 950-1250 (Oxford: Blackwell, 1987).

8 The Arab conquest began 642 C.E. with invasion of the Roman provinces of Palestine and Syria and ended in the year 711-725 C.E. 
The word antisemitism, derives from the terms Semite and Semitism. Both have been present since the eighteenth century in scholarly literature and were mostly used with regard to linguistic distinctions. Examples include August Ludwig von Schlözer who described in 1781 Hebrews, Arabs, and African Abyssinians as "Semites" and Franz Bopp who distinguished in 1816 between Indo-Germanic and Semitic languages. ${ }^{10}$ However, already Christian Lassen and Ernest Renan employ the term "Semite" with clearly racist connotations in $1847^{11}$ and $1857,{ }^{12}$ respectively. In criticism of Renan, the Jewish scholar Moritz Steinschneider introduced already in 1860 the concept of "antisemitic prejudices."13

The term antisemitism became prominent by the end of the nineteenth century. Wilhelm Marr ${ }^{14}$ is commonly claimed to have been the first to use it in his book The Victory of Judaism over Germanism: Regarded from a Non-confessional Point of View: Vae Victis! ${ }^{15}$ However, already Moshe Zimmermann has shown that the term antisemitism cannot be found in this book. ${ }^{16}$ Marr's pamphlet is clearly antisemitic in nature but does not use the word. Whoever coined the word antisemitism is beside the point, though.

9 A. L. Schlözer, "Von den Chaldäern," Repertorium fuer biblische und morgenlaendische Literatur 8 (1781): 161.

10 Cf. F. Bopp, Ueber das Konjugationssystem der Sanskritsprache in Vergleichung mit jenem der griechischen, lateinischen, persischen und germanischen Sprache (Frankfurt/Main: Windischmann, 1816).

11 Cf. C. Lassen, Indische Altertumskunde, 4 vols. (Bonn: H. B. König, 1847-1861), 1:494-96.

12 Cf. E. Renan, Études d'histoire religieuse (Paris: Lévy, 1880).

13 M. Steinschneider, Review of "Zur Charakteristik der semitischen Völker" by Heymann Steinthal, Hamaskir: Hebräische Bibliographie: Blätter für neuere und ältere Literatur des Judenthums 3 (1860): 16. The article by Steinthal was published in Zeitschrift für Völkerpsychologie und Sprachwissenschaft 1 (1860): 328-45 and reprinted in a collection of Steinthal's collected essays: Über Juden und Judenthum: Vorträge und Aufsätze, ed. G. Karpeles (Berlin: Verlag von M. Poppelauer, 1906), 91-104.

14 For W. Marr, see M. Zimmermann, Wilhelm Marr: The Patriarch of Anti-Semitism (Oxford: Oxford University Press, 1986).

15 W. Marr, Der Sieg des Judenthums über das Germanenthum: Vom nicht confessionellen Standpunkt aus betrachtet: Vae Victis! (Bern: Rudolph Costenoble, 1879). For examples for this attribution of the word antisemitism, see F. R. Nicosia, Zionism and Anti-Semitism in Nazi Germany (Cambridge: Cambridge University Press, 2008), 23.

16 Cf. e.g. M. Zimmermann, "Aufkommen und Diskreditierung des Begriffes Antisemitismus," in Ideologie-Herrschaftssystem-Wirkung in Europa: Festschrift für Werner Jochmann zum 65. Geburtstag, vol. 1 of Das Unrechtsregime: Internationale Forschung über den Nationalsozialismus, ed. U. Büttner (Hamburg: Hans Christians Verlag, 1986), 63. 
More important is how antisemitism should be defined. A popular distinction that is often made in the study of Jew-hatred is to discern religiously motivated Jew-hatred from racist Jew-hatred, the former would need to be classified as anti-Judaism while only the latter would need to be regarded as antisemitism. ${ }^{17}$ In this line of argument, all Jew-hatred before the predominance of racist Jew-hatred in the (late) nineteenth century would have to be described as antiJudaism while all racist Jew-hatred would be antisemitism.

This distinction is problematic for three reasons: (1) That racism and racist antisemitism begins only in the (late) nineteenth century needs to be questioned given the existence of racist or proto-racist forms of Jew-hatred long before this time. (2) While the term antisemitism is clearly modern in origin and in addition a misnomer that distorts an originally linguistic term, it is not unusual in historiography to describe ancient or medieval realities with modern terms. (3) That racist antisemitism is void of religious contents and meaning makes a particular European form of racist radical right-wing Jew-hatred absolute and elevates it to the paradigm of all other forms of antisemitism.

Two examples show how problematic the distinction between religiously motivated anti-Judaism and racist antisemitism is. My first example goes back to the alleged inventor of the term antisemitism, Wilhelm Marr. Marr himself uses the word antisemitism in describing the religiously driven Jew-hatred of the infamous court chaplain Adolf Stoecker and claims in this quote even that modern antisemitism began with Stoecker in the year 1878:

Modern antisemitism exists since the year 1878 when court chaplain Stoecker approached the Jewish question for the first time from his "Christian-social" point of view. ${ }^{18}$

Marr's description of the religiously motivated Jews-hatred of Stoecker shows that even the supposed inventor of the word antisemitism regarded religious Jew-hatred as much as antisemitism as his own racially driven version of it. The claim that in its origin the term antisemitism was reserved for racist Jewhatred is thus clearly wrong.

17 Cf. J. Heil, “'Antijudaismus' und 'Antisemitismus’: Begriffe als Bedeutungsträger,” Jahrbuch für Antisemitismusforschung 6 (1997): 105-6.

18 W. Marr, "Antisemitische Wucht und Verluste," in Österreichischer Volksfreund (1891). Preserved as a fragment in the estate of Marr. Quoted according to Zimmermann, "Aufkommen und Diskreditierung," 71, and Zimmermann, Wilhelm Marr, 112: "Der moderne Antisemitismus besteht seit dem Jahre 1878, als der Hofprediger Stoecker die jüdische Frage zum ersten Mal von seinem ‘christlich-sozialen' Blickpunkt aus anging.” Translation by the author of this article. 
A second example can be found in a passage from a speech that Hitler's deputy, Rudolph Hess, gave on May 14, 1935, for the German-Swedish society in Stockholm. Hess stated:

I myself was until then not an antisemite, but on the contrary defended the Jews based on the usual historical theory against their adversaries and persecutors. The facts of 1918 and later were so eye-catching that I was forced to convert to antisemitism, even though inwardly I was rather reluctant to revise my hitherto conviction about the innocence of persecuted Judaism. ${ }^{19}$

In this quote, several points deserve attention. First, Hess views his change of mind toward antisemitism as a movement from one belief system to another. Hess describes this movement from one belief system to another in both rational and religious terms. That he was "forced" to change his perspective mirrors the forceful emotional experience of conversion from one religion to another. It is thus no surprise that Hess refers to his change from philosemite to antisemite as a conversion. When Hess claims that "the facts of 1918 and later" would have changed his mind, this refers only seemingly to a rational analysis of historical events. It was, after all, not Germany's Jews who were responsible for its defeat at the end of World War I, and it was not Germany's Jews that caused the economic and political crisis following this defeat. Hess describes thus a much less rational thought-process. His interpretation of Germany's defeat and the crisis resulting from it was based on age-old prejudices about Judaism, which provided an interpretative grid that allowed Hess to make religious sense out of an existential crisis. Hess' sense that "the facts of 1918 and later were so eye-catching" shows furthermore that they captured his thought process emotionally, that they led him from one set of perceptions to a very different set. This is not a process of rational education but rather one of emotional-religious-transformation.

The two examples show that religious and racist antisemitism cannot easily be separated from each other. However, not only can a person like Rudolph Hess, whose antisemitism was clearly racist in character, describe his racist Jew-hatred

19 R. Hess, “An die Ausländer guten Willens,” in Reden (München: Zentralverlag der NSDAP, Franz Eher Nachf., 1938), 104: "Ich selbst war bis dahin kein Antisemit, sondern nahm in Gegenteil auf Grund der üblichen Geschichtslehre die Juden gegenüber ihren Widersachern und Verfolgern in Schutz. Die Tatsachen von 1918 und später waren aber so in die Augen springend, daß ich mich zum Antisemitismus bekehren mußte, so sehr ich mich auch innerlich dagegen sträubte, meine bisherige Überzeugung von der Unschuld des verfolgten Judentums berichtigen zu müssen.” Translation and emphasis by the author of this article. 
in religious terms. Together with Maxine Grossman I have elsewhere argued that antisemitism in itself is a religious phenomenon. ${ }^{20}$

Given the complicated history of how the word antisemitism developed, it can come hardly as a surprise that scholars and activists in the fight against Jew-hatred define the term differently. A quotation by Steven Beller brings the range of definitions to the point:

\begin{abstract}
Antisemitism is a hatred of Jews that has stretched across millennia and across continents; or it is a relatively modern political movement and ideology that arose in Central Europe in the late 19th century and achieved its evil apogee in the Holocaust; or it is the irrational, psychologically pathological version of an ethnocentric and religiocentric anti-Judaism that originated in Christianity's conflict with its Jewish roots-and achieved its evil apogee in the Holocaust; or it is a combination of all of these. ${ }^{21}$
\end{abstract}

As stated, the present article does not offer room for an extensive discussion on how to define antisemitism. While the term is clearly a misnomer deriving from a linguistic category, it is nevertheless too established to describe any form of Jewhatred otherwise. In many countries of the world, governments have accepted the so-called working definition of antisemitism proposed by the International Holocaust Remembrance Alliance (IHRA):

Antisemitism is a certain perception of Jews, which may be expressed as hatred toward Jews. Rhetorical and physical manifestations of antisemitism are directed toward Jewish or non-Jewish individuals and/or their property, toward Jewish community institutions and religious facilities. ${ }^{22}$

While the IHRA's definition comes out of a political and diplomatic process, scholarly discourse was carefully incorporated and considered when it was phrased. ${ }^{23}$ Although the working definition of antisemitism is not legally bind-

20 Cf. A. Lange and M. Grossman, "Jews and Judaism between Bedevilment and Source of Salvation: Christianity as a Cause of and Cure against Antisemitism," in Comprehending and Confronting Antisemitism: A Multi-Faceted Approach, vol. 1 of An End to Antisemitism!, ed. A. Lange et al. (Berlin: De Gruyter, 2019), 133-64.

21 S. Beller, Antisemitism: A Very Short Introduction (Oxford: Oxford University Press, 2007), 1. 22 "Working Definition of Antisemitism," International Holocaust Remembrance Alliance, issued July 19, 2018, accessed September 7, 2020, https://www.holocaustremembrance.com/ sites/default/files/press_release_document_antisemitism.pdf.

23 See M. Weitzman, "The IHRA Working Definition of Antisemitism," and D. Porat, "The Working Definition of Antisemitism: A 2018 Perception," in Comprehending and Confronting Antisemitism: A Multi-Faceted Approach, vol. 1 of An End to Antisemitism!, ed. A. Lange et al. (Berlin: De Gruyter, 2019), 463-73 and 475-87. 
ing, it provides nevertheless an internationally recognized and accepted common ground on how to define antisemitism and is thus applied in my present survey on antisemitism in antiquity as well.

This is all the more appropriate as the working definition consciously avoids distinctions of racially and religiously motivated Jew-hatred by not even mentioning these terms. For the working definition, all forms of Jew-hatred are antisemitism, be it the religious demonization of Jews since antiquity or their racist discrimination and persecution by the Nazis or any variety of enmity against Jews. ${ }^{24}$

\section{In Which Ways Were Jews Persecuted?}

To better understand the history of the persecution of Jews, it is helpful to understand the different forms of how Jews were persecuted. This is all the more important as such categorizations allow us to better perceive the interconnectedness of devaluating Jewish culture and religion on the one hand and antisemitic pogroms and genocide on the other hand. I distinguish between three principle forms of antisemitic persecution in antiquity: (1) cultural persecution, (2) legal persecution, and (3) physical persecution.

Between each of these forms of persecution large grey zones exist, and they often are deeply intertwined. An example for such a grey zone would be the banishment of a Jewish population from a country or city as it involves both physical violence and legislative as well as judicial acts. Furthermore, the above forms of persecution are not privy to antisemitism but can be observed with the discrimination and persecution of other minorities and groups as well. While the concepts of physical and legal persecution do not need much explanation, the concept of cultural persecution is rarely used in the study of antisemitism.

1. In the history of antisemitism, physical persecution involved and involves all acts of physical violence against Jewish individuals, groups, institutions, or items owned by such persons or entities. Such acts of violence include physical attacks on Jewish individuals, the burning of a synagogue or the looting of a Jewish shop. The Nazi concentration camps represent of course the sad climax of the physical persecution of Jews.

24 For my own view on the religious character of all forms of antisemitism, see Lange and Grossman, "Jews and Judaism between Bedevilment and Source of Salvation"; A. Lange and M. Grossman, "The Religious Nature of Antisemitism: The Examples of the Pittsburgh and Poway Shooters," in Europäische Werte, Rechtsstaat, Sicherheit (forthcoming). 
2. Antisemitic legal persecution uses both legislative and judicial means to target Jews and discriminate against making Jewish life either impossible or very difficult. One of the most notorious examples of the legal persecution of Jews are the so-called Nuremberg Race Laws of the Nazis. For the period under investigation in this essay, Christians had neither legislative nor judiciary powers. The legal persecution of Jews was thus restricted in antiquity to pagan Jew-hatred. While I will demonstrate below that legal persecutions of Jews happened in the pagan antiquity, sources documenting such incidents are rare and much of this part of the persecution history of Judaism is lost in the mists of time.

3. While the concepts of physical and legal persecution are easy to comprehend, the term cultural persecution can be understood as any form of non-violent and non-legal/judicial discrimination against Jews targeting their cultural heritage and/or cultural identity.

The concept of cultural persecution is not a common one and is rarely used. To my knowledge the earliest attestation is in an article by Grunfeld who uses the term "cultural persecution" to describe the eradication of the German intelligentsia during the Nazi period. ${ }^{25}$ Connected to the idea of cultural persecution but more common is the concept of cultural genocide. Although not using the term cultural genocide, Raphael Lemkin included this concept even in his definition of genocide:

\footnotetext{
By "genocide" we mean the destruction of a nation or an ethnic group ... Generally speaking, genocide does not necessarily mean the immediate destruction of a nation, except when accomplished by mass killings of all members of a nation. It is intended rather to signify a coordinated plan of different actions aiming at the destruction of essential foundations of the life of national groups, with the aim of annihilating the groups themselves. The objectives of such a plan would be disintegration of the political and social institutions, of culture, language, national feelings, religion, and the economic existence of national groups, and the destruction of personal security, liberty, health, dignity, and even the lives of the individuals belonging to such groups. Genocide is directed against the national group as an entity, and the actions involved are directed against individuals, not in their individual capacity, but as members of the national group. ${ }^{26}$
}

25 F. V. Grunfeld, "Cultural Persecution: The First Step Towards Genocide," The UNESCO Courier: A Window Open on the World 38 (1985): 6-7.

26 R. Lemkin, Axis Rule in Occupied Europe: Laws of Occupation, Analysis of Government, Proposals for Redress (Washington: Carnegie Endowment for International Peace Division of International Law, 1944), 79, emphasis by the author of this article. For Lemkin and the coining of the term "genocide," see e.g. J. B. Quigley, The Genocide Convention: An International Law Analysis (Hampshire: Ashgate, 2006). 
As the cultural aspect of genocide was already seen by the creator of the term "genocide," cultural genocide ${ }^{27}$ was an integral part of the first drafts of the United Nations genocide convention. In these drafts, the concept of cultural genocide referred to acts of forced assimilation or "acts intended to destroy the language, religion or culture of a national, racial or religious group." ${ }^{28}$ However, the term "cultural genocide" was omitted in the 1948 genocide convention of the United Nations itself. ${ }^{29}$

The history of the terms cultural genocide and cultural persecution shows thus already: The concept of cultural genocide pertains to acts of discrimination, to acts of law and law enforcement, as well as to acts of physical violence. Cultural persecution on the other hand describes acts against the intangible cultural heritage of a people, group, culture or religion. ${ }^{30}$ Antisemitic cultural persecution includes thus all forms of agitation against and discrimination of Jews that are not necessarily connected with legal, social, and economic measures or physical violence.

The above discussion should not imply that other forms of antisemitic persecution, such as economic or social persecution, did not exist in antiquity as well. Already my brief discussion of the three forms of antisemitic persecution still evident for antiquity shows that to cover the physical, legal, and cultural persecution of Jews in antiquity exceeds what is possible in one brief article. The vastness of this period, the large amount of sources from this period especially for the cultural persecution of Jews, and the different historical events that would need to be addressed render comprehensiveness an impossible goal in one article. I will therefore approach my subject in the present contribution by way of select examples. For this purpose, I will first address the cultural,

27 For the concept of cultural genocide, see e.g. E. Novic, The Concept of Cultural Genocide: An International Law Perspective (Oxford: Oxford University Press, 2016) and L. Bilsky and R. Klagsbrun, “The Return of Cultural Genocide?” European Journal of International Law 29, no. 2 (2018): 373-96. More recently, the idea of cultural genocide became also a part of contemporary antiZionist propaganda and even scholarship. An example for the latter is the book by L. Davidson, Cultural Genocide (Brunswick: Rutgers University Press, 2012), esp. 65-88.

28 UN ECOSOR, $3^{\text {rd }}$ sess., Report of the Ad Hoc Committee on Genocide 5 April to 10 May 1948, Supp. (No. 6), 6; UN Doc. E/794 (1948). Quoted according to Quigley, Genocide Convention, 9. 29 "Convention on the Prevention and Punishment of the Crime of Genocide," United Nations, issued December 9, 1948, accessed November 2, 2020, https://www.un.org/en/genocidepre vention/documents/atrocity-crimes/Doc.1_Convention $\% 20$ on $\% 20$ the $\% 20$ Prevention $\% 20$ and $\%$ 20Punishment\%20of\%20the\%20Crime\%20of\%20Genocide.pdf.

30 Novic, The Concept of Cultural Genocide, 143 and passim. For the idea of cultural persecution, see esp. $142-68$. 
legal, and physical persecution of Jews in pagan antiquity before engaging with the cultural persecution of Jews by ancient Christians.

\section{Pagan Jew-Hatred in Antiquity}

When studying Jew-hatred in the ancient Mediterranean world, Jew-haters can be clearly divided into two camps, that is, the pagan world and Christianity.

1. The pagan world was shaped by a whole range of polytheistic religions which normally tolerated each other. At least in the case of the Roman Empire, the official state religion has to be distinguished from all other cults. As long as Roman citizens venerated the Roman gods-and during the time of the principate-also the Emperor, they were free to worship as many other deities as they wanted to. This basic polytheistic tolerance did not exclude the ridicule and discrimination of other cultures and religions, though. ${ }^{31}$ As Jewish monotheism made the participation in the polytheistic plurality of the Hellenistic world of the Roman Empire difficult, the Jewish belief in one God turned Judaism into a target for such ancient polytheistic contempt. However, pagan Jew-hatred had many causes and any monocausal explanation for it falls short of understanding the pagan enmity against Jews in the ancient Mediterranean world.

2. Christianity, however, was shaped by the same idea of religious exclusivity and election as Judaism. Christian monotheism claimed, though, the God of the Jewish parent religion for itself and declared itself as the new beneficiary of the promises of salvation the God of Judaism made to his chosen people. When Christianity separated from Judaism, the Christian monotheistic claim to the God of Judaism inspired the Christian rejection of Judaism on religious grounds. Early Christians formed thus a religious group identity that constructed the essence of Christian existence as being not Jewish. In other words, Christian group identity was constructed in rejection of Judaism while at the same time appropriating the Jewish idea of the chosen people for Christianity itself.

A further significant difference between pagan and Christian Jew-hatred in the ancient Mediterranean world was that until the Constantinian shift, Christians did not have any state authority, while pagan Jew-hatred could and did express

31 Cf. e.g. Isaac, The Invention of Racism. 
itself during the same time period repeatedly by way of state violence against Jews.

Because of these principal differences between pagan and Christian Jewhatred, in this essay, I will first discuss pagan Jew-hatred through the Constantinian shift before I will turn to Christian Jew-hatred. Both topics are very big and can thus be discussed only by way of selected examples. For reasons of space, I will also have to restrict my elaborations to the ancient Mediterranean world and cannot engage with any form of ancient Jew-hatred beyond this geographical region.

The conquest of Persian Egypt by Alexander the Great in the late fourth century B.C.E. and the founding of a Hellenistic Ptolemaic kingdom in Egypt in 305 B.C.E. as one of the most important successor states of Alexanders realm mark two important turning points in the history of the ancient Mediterranean world. After these momentous events, the cultural and physical persecution of Jews increased significantly. Ptolemaic Egypt was governed by a small GrecoMacedonian elite, which ruled over a large indigenous Egyptian population. The relationship between Greeks and Egyptians was tense, and even after several generations the Greeks were recognized as foreign conquerors by the indigenous population of Egypt.

To maintain their power and secure tax revenue from Egypt, the Ptolemaic foreign rulers brought various groups of people from other parts of the Eastern Mediterranean into Egypt. They deployed these immigrants as policemen, soldiers, and state officials. Among them, Jews formed a particularly large and visible group. Jews became thus the public face of Ptolemaic state authority and state violence and were therefore appreciated neither by the indigenous population of Egypt nor by its Greco-Macedonian inhabitants. Until the downfall of Ptolemaic Egypt in the year 30 B.C.E., the hatred which should have targeted the Greco-Macedonian ruling class or the Greco-Macedonian government of Egypt was thus directed by both Greeks and Egyptians toward the Jews of Egypt.

With its museum and library-the latter famous even today-Alexandria was the cultural capital of the ancient Mediterranean world. However, Alexandria was also a center of Jew-hatred in the Hellenistic world, and a significant number of Alexandrian scholars were invested in antisemitic polemics. Given the city's cultural importance and recognition, Greco-Egyptian Jew-hatred spread from Alexandria all over the ancient world with ease. The Jew-hatred exported from Ptolemaic Egypt merged with local traditions of Jew-hatred elsewhere in the ancient world making them even more potent.

After Egypt became part of the Roman Empire, the Ptolemaic military and police became defunct. The Jewish elements in the Ptolemaic military seized with them to exist and were thus unable to provide continued protection for 
the Jews of the region. While with the demise of the Greco-Macedonian government, the original cause for Greco-Egyptian Jew-hatred did not exist anymore, the lack of protection for the Jews of Egypt allowed for an escalation of antisemitism in Egypt. ${ }^{32}$

\title{
3.1 Cultural Persecution of Jews in Pagan Antiquity
}

\begin{abstract}
Having guessed, for the number of those expelled, the same figure as Lysimachus (he says there were 110,000), he offers an amazing and persuasive reason for how, he says, the sabbaton got its name. When they had travelled for six days, he says, they contracted swellings in the groin and for this reason rested on the seventh day, after arriving safely in the land that is now called Judea; and they called that day sabbaton, preserving the Egyptian language, for the Egyptians call the inflammation of the groin sabbatōsis. ${ }^{33}$
\end{abstract}

This Sabbath polemic was part of the now lost work of the Egypto-Alexandrian writer and scholar Apion. It is preserved as a quotation fragment in Josephus' apology Against Apion. That Josephus compares Apion's report about Israel's time in the desert and its arrival in Judea with the one by Lysimachus, demonstrates already that Apion was by far not alone in his antisemitic attitude toward Judaism. Other Greek and Latin authors of whom antisemitic passages are preserved include Agatharchides of Knidos, Apollonius Molon, Chaeremon, Diodorus Siculus, Manetho, Mnaseas, and Plutarch on the Greek side and Ammianus Marcellinus, Cicero, Juvenal, Martial, Petronius, Seneca, and Tacitus on the Latin side.

Apion's Sabbath polemic is not only particularly disgusting but also particularly perfidious. Apion satirizes the Exodus, desert, and conquest narratives and in doing so attacks the Sabbath as a central institution of Jewish religious identity. Different from the biblical narrative, in a distorted caricature, Apion depicts the Jews not as the chosen people but as a group which suffered during its flight from Egypt from a venereal disease. In this way, Apion wants to contest Israel's claim to be the chosen people and thus to disqualify all Jews as human beings, who are especially despicable as proven by their venereal disease. Disease was regarded not only in Judaism but also in other ancient religions as an indicator of impurity. That the Torah contains a whole range of purity legislation demonstrates how important the issue of religious purity was for ancient

32 Given the survey character of the following overview, I will not engage in a discussion with scholarly literature.

33 Translation according to J. M. G. Barclay, Against Apion: Translation and Commentary (Leiden: Brill, 2007), 178-79. 
Judaism. With his polemic, Apion negates thus not only the key narrative that establishes Jewish religious identity but also the special significance of religious purity in Judaism. Even worse, Apion claims that a venereal disease forced the Jews to rest at the seventh day after the Exodus from Egypt. The Sabbath would thus not memorialize the resting of God after six days of creation but a resting that was forced on Israel by a venereal disease. Apion connects in this way one of the most important religious institutions of (ancient) Judaism with an inflammation of the groin. Thus, Apion negates and ridicules both key Jewish scriptures and a key ritual of the Jewish religion. This exposure to ridicule happens on a scale that both institutions become inacceptable to anyone believing Apion.

Apion's approach is even more perfidious than a modern human being can imagine. A large part of the ancient population could neither read nor write. Even those humans who were able to read and/or write had very limited access to libraries and thus written texts. To verify Apion's claims was thus simply impossible to most ancient audiences. Most of Apion's readers thus would have accepted his slander and would have helped to spread Apion's message of Jewhatred without questioning it.

If one tries to abstract from Apion's approach theoretically, it becomes evident that with his retelling of the Exodus, desert, and conquest narratives, Apion wants to anchor not only a negative depiction of these key religious Jewish legends but also a negative perception of Judaism in the cultural memory of the Greco-Roman world. As explained above, I characterize this approach as cultural persecution. The intertextual strategy which Apion employs for his cultural persecution of Judaism, that is, the way in which he rewrites Jewish texts, can best be described as counter narrative.

Apion reinterprets the Torah and the Sabbath in a specifically antisemitic way. With the interpretative rewriting of the Exodus, desert, and conquest narratives, Apion creates a new intertext, which he speaks into both the Jewish and Hellenistic culture to anchor them in their respective cultural memories. In the Hellenistic cultural memory, Apion's counter narrative is supposed to create a memory space that evokes hatred and disdain for the Jewish cultural memory and thus for Judaism. In the Jewish cultural memory, Apion wants to change with his counter narrative the desert and Sabbath narratives to such an extent that Judaism would begin to hate itself. This attempt on the cultural persecution and the cultural genocide of Judaism could succeed in antiquity all the more easily as even the Jews themselves had only limited access to written copies of their scriptures. Falsification of Apion's slander was therefore difficult to achieve. With respect to the Jewish cultural memory, Apion's slander can be compared to an aggressive computer virus that can destroy a computer with ease. 
The example of Apion has shown that antisemitic cultural persecution employs intertextual strategies to achieve its goal. It wants to shape

1. the perception of another culture or minority in the cultural memory of its own culture in a distinctly negative way,

2. in order to influence the self-perception of this alternate culture or minority in its own cultural in such a negative way that self-rejection becomes unavoidable.

However, in antiquity, cultural persecution was neither restricted to counter narrative, nor did it always derive from Hellenistic scholarship. Discriminating jokes are a further example for the ancient cultural persecution of Jews. Defamation and discriminating interpretations of the Jewish scripture all want to achieve the same goal, that is, the cultural genocide of Judaism. That this strategy was successful is demonstrated by, for example, an Egyptian papyrus from the first century B.C.E. (C.Pap.Jud. I:141):

\begin{abstract}
Herakles to the manager of Ptolemaios many greetings and good wishes of good health. I have asked Iap[...] in Memphis, about the priest of Tebtunis, to write a letter for him, in order that I may know how things stand. I ask you to take care that he does not fall into a trap and take him by the hand; when he will have need of anything, do for him as you do for Artemidoros and, in particular, give me the pleasure of finding the same lodgings for the priest: you know that they despise (A. L.) the Jews. Greet [...]ibas, Epimenes and Tryphonas, ... and take care of yourself. ${ }^{34}$
\end{abstract}

Beyond the effectiveness of the cultural persecution of Jews, this papyrus illustrates also that Jews were discriminated against in Egyptian daily life and had to live in fear of antisemitic acts of violence.

\title{
3.2 Physical Persecution of Jews in Antiquity
}

The sources documenting the physical persecution of Jews in antiquity are sparse and often difficult to analyze. In many cases, these sources confine themselves to brief remarks notifying the mass slaughter or banishment of the Jewish population of a given city. Due to the abbreviate nature of these reports, what motivated such acts of violence remains unclear. Were Jews persecuted and even killed, because of their Judaism or, for example, because they instigated

34 J. Mélèze Modrzejewski, The Jews of Egypt: From Rameses II to Emperor Hadrian, trans. R. Cornman (Princeton: Princeton University Press, 1997), 154-55. 
a revolt against the Roman Empire? Did a violent response to the Jewish refusal to venerate other deities go back to a polytheistic lack of understanding or was it motivated by antisemitism? Were individual acts of violence against Jews isolated events that were detached from Jew-hatred or were they motivated by the victimizers' antisemitism? The grey areas between the implied answers to the above questions are of course significant and even more difficult to evaluate given the nature of the ancient sources.

Next to the abbreviate nature of ancient reports about violence against Jews, texts about ancient physical persecution of Jews were often embellished and few details about the historical events can thus still be gained beyond such embellishments. Especially difficult is the source situation for the second and third centuries C.E. Until more sources are discovered and/or identified, it remains simply unknown if physical persecutions of Jews happened in this time period.

The complicated source situation does however not imply that no physical persecution motivated by ancient Jew-hatred happened in antiquity. It only means that in most cases of physical persecution of Jews in antiquity, we simply do not know whether it was motivated by the perpetrators' antisemitism or by other factors.

In view of the difficult source situation, the list of possible physical persecution of Jews in antiquity is more than alarming. This is all the more the case as the below list does not even recognize minor incidents of violence against Jews in antiquity:

- 410 B.C.E., Egypt: Destruction of the Jewish temple on Elephantine-an island in the Nile river in today's southern Egypt

- 331 B.C.E., Babylon: Jews refuse to participate in the rebuilding of the Marduk temple in Babylon ordered by Alexander the Great. Alexander responds with state-organized persecution of Babylonia's Jews. These events might provide the historical context for the Purim Story in the book of Esther.

- 175-164 B.C.E., Jerusalem and Judea: The persecutions connected with the so-called Hellenistic religious reforms of Antiochus IV Epiphanes

- 139 B.C.E., Rome: Banishment of all Jews from Rome by the senate

- 19 C.E., Rome: Banishment of all Jews from Rome by Emperor Tiberius

- 31 C.E., Rome: Persecution of the Jews from Rome by the pretorian prefect of Rome, Sejanus-tolerated by Emperor Tiberius

- Ca. 35 C.E., Babylonia: Pogrom in Seleucia on the Tigris

- $\quad 38-41$ C.E., Egypt: The Flaccus pogrom in Alexandria (see below for details)

- 49 C.E., Rome: Banishment of all Jews from Rome by Emperor Claudius

- 66-70 C.E., Judea, Syria, and Egypt: Riots and pogroms during the First Jewish War in Ashkelon, Antiochia, Caesarea, Damascus, Gadara, Hippos, 
Ptolemais, Scythopolis, Tyrus, and in a group of Syrian cities as well as in Egypt

The arguably best-known physical persecution of Jews in antiquity is the socalled Flaccus pogrom ${ }^{35}$ in Alexandria during the years 38-41 C.E. Given that an eyewitness account of the events is preserved, I will discuss the Flaccus pogrom as an example for the physical persecution of Jews in antiquity.

Since Egypt became a part of Roman Empire in the year 30 B.C.E., the influence and importance of the country's Jews declined. With the abrogation of the Ptolemaic army, the Jews of Egypt had no military function anymore. The Jews of Egypt lost thus a key safety factor. It was this loss of protection that made the Flaccus pogrom possible.

Aulus Avilius Flaccus (d. 39 C.E.) was a Roman eques who served between 32-38 C.E. as the Roman prefect of Egypt. Flaccus was a confidante of Emperor Tiberius who got into disapproval during the reign of Caligula. Philo describes in his essay In Flaccum, how the Greek inhabitants of Alexandria used these circumstances to incite Flaccus against the Jews of the city:

(21) All of them united in developing a plot that was most grievous to the Jewish community. In a private conversation with Flaccus they said: (22) "Gone are the expectations you had of the boy Tiberius Nero; gone too is your next hope, your friend Macro, and what you can expect from the emperor does not look very favorable either. For this reason, we have to find a very powerful intercessor by whom Gaius may be propitiated. (23) That intercessor is the city of Alexandria, which has been honored from the beginning by the entire imperial family, especially by the present master. Intercede it will, if it receives some present from you. And you can give it no greater bonus than by handing over and abandoning the Jews." (Philo, In Flaccum 4.21-23) ${ }^{36}$

35 The application of a modern term like "pogrom" to a persecution of Jews in antiquity is debated. However, to use modern terms for the study and description of ancient history is unavoidable. Important is not that the word "pogrom" is modern and that it derives from the Russian word погром [pe'grom] ("mayhem, carnage") which was used to describe the persecution of Jews in the 1880s. Instead, it needs to be asked if a given incident of violence against Jews fits the scholarly definition of a pogrom as outlined, for example, by W. Bergmann, "Pogrom," in Begriffe, Theorien, Ideologien, vol. 3 of Handbuch des Antisemitismus, ed. W. Benz (Berlin: De Gruyter, 2010), 269-70. Cf. ibid., "Pogrome: Eine spezifische Form kollektiver Gewalt," Kölner Zeitschrift für Soziologie und Sozialpsychologie 50 (1998): 644-65; and W. Bergmann, "Pogrome," in Internationales Handbuch der Gewaltforschung, ed. W. Heitmeyer and J. Hagan (Wiesbaden: Westdeutscher Verlag, 2002), 441-60. In my opinion, the latter is the case with the Alexandrian Flaccus pogrom.

36 English translations according to Philo, Philo's Flaccus: The First Pogrom: Introduction, Translation, and Commentary, trans. P. W. van der Horst (Leiden: Brill, 2003), 58, 65, 66-67. 
When Flaccus ordered that idols of the Emperor should be erected in Alexandria's synagogues, riots arose because the veneration of idols is prohibited in Jewish law, and the veneration of a human as a deity is a grave offense against Jewish religious law (Exod 20:4-5; 22:19; 34:14; Deut 12:30; m Sanh. 7:6; b Sanh. 60b; 61b; cf. Sanh. $60 \mathrm{~b} ; 63 \mathrm{a})$. In response to the Jewish riots, Flaccus gave the Jews of Alexandria the legal status of foreigners. As a consequence, those Jews of Alexandria who in part for generations held the status of citizens as well as those Jews who were classified as Hellenes lost important (tax) privileges.

When on his way to Judea the Jewish king Herod Agrippa I made a stopover in Alexandria in 38 C.E., the Greeks of the city slandered him with antisemitic satire. They dressed a well-known madman in doormats and gave him a crown and scepter made of papyrus. Furthermore, they addressed the madman as "marin," using the Aramaic word for "Lord." In response to this satire, the incited Greeks of Alexandria stormed the synagogues of the city and erected statutes of the Emperor in them. They plundered Jewish homes and stores, evicted, maltreated, and murdered Jews. Philo describes this pogrom as carefully planned, prepared, and executed:

He himself became everything: accuser, enemy, witness, judge, and executioner. But he then added to the first two (crimes) a third one, namely, he gave permission to those who wanted to plunder the Jews, as at the sacking of a city. (55) Well, what do people do when they get this license? The city has five districts, named after the first letters of the alphabet as we used to write it. Two of the districts are called the Jewish quarters because the majority of the inhabitants are Jews. In the other quarters there are also quite a number of Jews, although scattered about. So, what did they do then? They expelled the Jews from four of the five quarters and drove them together into a very small corner of the one left. (56) Because of their great numbers they (the Jews) flooded the beaches, the dunghills and the tombs, deprived of all their belongings. The enemies, however, ran to the houses left empty and plundered them; they divided the booty among themselves as if it were war. Since no one hindered them, they broke into the workshops of the Jews, even though these were closed because of the mourning for Drusilla, and they brought out all they found there, which was quite a lot. They carried it to the middle of the marketplace, handling other people's property as if it were their own. (57) The unemployment, which was the consequence of this, was an evil that was even more unbearable than the plundering. The financers had lost their capital and no one was permitted to practice his usual business, neither farmer, nor shipper, nor merchant, nor artisan. So, poverty was brought down on them from two sides: first they were robbed, because in one day they were stripped of all their property and lost all they had, and second they were no longer able to make a living from their regular jobs. (Philo, In Flaccum, 8.55-57)

In addition, large parts of Alexandria's population participated spontaneously in the pogrom. Next to all the Jew-hatred that is evident in Philo's report, Philo leaves no doubt that economic factors motivated this ancient pogrom as well: 
(69) If the persons who were called to collect brushwood were too slow, they would burn the owners using their own furniture taken from the spoil, thus robbing them first of their most costly articles and then setting on fire anything that was not very useful to serve instead as timber. (70) Many also they bound by one foot at the ankle and dragged them around while still alive, meanwhile leaping on them and crushing them to pieces, thus devising the most cruel form of death. (71) Even when they were dead, the endless fury of their enemies did not come to an end; they inflicted still worse outrages on their dead bodies. They dragged these through-I would almost say-every lane of the city until the corpses had lost their skin, their flesh and muscles because these had been pulverised by the unevenness and toughness of the ground and were totally destroyed because all the constituent parts of the organism had been separated and dispersed in all directions. (Philo, In Flaccum 9.69-71)

After these events, Flaccus ordered that the Jews of Alexandria had to live in the city's Delta quadrant. Although the Delta quadrant was a traditional home to many of Alexandria's Jews, they had never before been restricted to it, and many Jews had lived in other parts of the city as well. With his edict Flaccus created thus the first Jewish ghetto in world history. The plundered Jews of Alexandria had to suffer starvation as they were not allowed to work outside the Delta quadrant. Jews who left the Delta quadrant were stoned, slayed, burned, or killed in other ways. Even crucifixions are reported to have occurred in one of Alexandria's arenas. In this situation and in celebration of the Emperor's birthday, Flaccus arranged for a public flogging of the thirty-eight members of Alexandria's Jewish council of elders on August 31, which was a Shabbat. The flogging was so brutal that many of the elders died from it.

In October of the year 38 C.E., Flaccus was deposed by Emperor Caligula. One year later he was executed on the island of Andros. In terms of how far Caligula responded with these measures to a letter from Herod Agrippa remains an open question. ${ }^{37}$

In response to the events described above, the Jewish and Greek inhabitants of Alexandria sent two delegations to Rome to negotiate about the pogrom and the continued persecution of Alexandria's Jews with the Emperor. The negotiations came to a conclusion only during the reign of Emperor Claudius (41-54 C.E.) after Emperor Caligula was murdered on January 24, 41 C.E. In a public letter to the prefect of Egypt, of which at least one copy is preserved today (P.Lond. 1912), Claudius summarizes the results of the negotiations and prohibits his divine worship in Alexandria and elsewhere. The papyrus makes clear that the Emperor would respond to renewed violence in Alexandria with the deployment of

37 Cf. Philo, On the Embassy to Gaius. General Indexes, trans. F. H. Colson (Cambridge: Harvard University Press, 1962), 269-75, 333. 
Roman legions, regardless of which party instigated it. The Jews of Alexandria are entitled to the special cooperative rights that they had enjoyed before the Flaccus pogrom. However, they are denied the citizenship of Alexandria for all times. The latter applied also to those Jews who had held Alexandria's citizenship before the Flaccus pogrom-in some cases for many generations. The Jews of Alexandria became thus guests of the city which were protected by the Emperor and had special legal rights. That Jews had lived in Alexandria since the founding of the city, that they represented a large part of its population, and that they contributed greatly to the city's wealth and prosperity all did not matter.

\subsection{The Legal Persecution of Jews in Pagan Antiquity}

The topic of the legal persecution of Jews in antiquity is subject to many problems and is much more difficult to address than it appears. The earliest collections of ancient law that are still preserved today date to late antiquity. From antiquity itself only few reports about laws that concern Jews are preserved and not all of these ancient laws about Jews discriminate against them. If an ancient regulation that discriminates against Jews is preserved, we know often so little about it that it is difficult to determine whether a law that disadvantages Jews is of antisemitic character or not.

Despite these caveats, it can be assumed with a reasonable degree of certainty that already during the early Roman principate, large parts of the Jewish diaspora were confronted with antisemitic regional legislation or antisemitic legal practices. An example of how Roman Emperors responded to this kind of legal persecution and discrimination against Jews in the Greek cities of their realm is the Jewish legislation of Augustus.

Josephus Flavius describes in his historical work, Jewish Antiquities, how Herod the Great (73-4 B.C.E.) met with Marcus Vipsanius Agrippa (63-12 B.C.E.) in Ionia in the year 13 B.C.E. Agrippa was a close friend of Augustus and was responsible for the eastern provinces of Rome during the years 23-13 B.C.E. The Ionian Jews seem to have used the opportunity of this meeting to complain about the legal discrimination they experienced from the administration of the Greek cities they lived in. Josephus reports:

But now, when Agrippa and Herod were in Ionia, a great multitude of Jews, who dwelt in their cities, came to them, and laying hold of the opportunity and the liberty now given them, laid before them the injuries which they suffered, while they were not permitted to use their own laws, but were compelled to prosecute their law-suits, by the ill usage of 
the judges, upon their holy days, and were deprived of the money they used to lay up at Jerusalem, and were forced into the army, and upon such other offices as obliged them to spend their sacred money; from which burdens they always used to be freed by the Romans, who had still permitted them to live according to their own laws. (Josephus A.J. $16.27-28)^{38}$

The Roman Empire did not only permit its Jews to live according to their own customs but granted them their own jurisdiction as well as to pay the yearly temple tax. The Greek authorities of the Ionian cities denied their Jews exactly these privileges. Beyond that, they forced their Jews to prosecute their lawsuits on Jewish holidays and on Shabbat, that is, on days for which Jewish religious law prohibited such activities. Furthermore, Greek authorities forced them to serve in the army which meant participation in religious rites that Jews considered idolatry. Herod obtained from Agrippa the abolition of these discriminatory legal practices against Ionia's Jews.

What Josephus describes for the year 13 B.C.E. regarding the case of the Ionian cities, he repeats later on for all Jews of Asia Minor and the Cyrenaica in a lengthy excursus, which he inserted into his description of the reign of Herod the Great.

\begin{abstract}
Now the cities ill-treated the Jews in Asia, and all those also of the same nation which lived ill Libya, which joins to Cyrene, while the former kings had given them equal privileges with the other citizens; but the Greeks affronted them at this time, and that so far as to take away their sacred money, and to do them mischief on other particular occasions. When therefore they were thus afflicted, and found no end of their barbarous treatment they met with among the Greeks, they sent ambassadors to Caesar on those accounts, who gave them the same privileges as they had before, and sent letters to the same purpose to the governors of the provinces, copies of which I subjoin here, as testimonials of the ancient favourable disposition the Roman emperors had towards us. (Josephus A.J. 16.160-161)
\end{abstract}

The main point of contention between the Jews of Cyrenaica and Asia Minor on the one hand and the authorities of the Greek cities they lived in on the other hand seems to have been the Jewish temple tax. Beyond the obstruction of collecting the temple tax, other forms of legal persecution seem to have taken place as well. Emperor Augustus responded by way of a decree that was valid everywhere in the Roman Empire and that was intended to end all Greek legal persecutions of Jews (see Josephus, A.J. 16.162-165). Augustus not only guaranteed the

38 English translations of book sixteen of Josephus's Antiquities and Josephus' Jewish War are according to W. Whiston, The New Complete Works of Josephus (Grand Rapids: Kregel, 1999). 
collection of the temple tax but also put various legal practices directed against Jews under penalty.

\begin{abstract}
Caesar Augustus, high priest and tribune of the people, ordains thus: Since the nation of the Jews hath been found grateful to the Roman people, not only at this time, but in time past also, and chiefly Hyrcanus the high priest, under my father Caesar the emperor, it seemed good to me and my counselors, according to the sentence and oath of the people of Rome, that the Jews have liberty to make use of their own customs, according to the law of their forefathers, as they made use of them under Hyrcanus the high priest of the Almighty God; and that their sacred money be not touched, but be sent to Jerusalem, and that it be committed to the care of the receivers at Jerusalem; and that they be not obliged to go before any judge on the sabbath day, nor on the day of the preparation to it, after the ninth hour. But if any one be caught stealing their holy books, or their sacred money, whether it be out of the synagogue or public school, he shall be deemed a sacrilegious person, and his goods shall be brought into the public treasury of the Romans. And I give order that the testimonial which they have given me, on account of my regard to that piety which I exercise toward all mankind, and out of regard to Caius Marcus Censorinus, together with the present decree, be proposed in that most eminent place which hath been consecrated to me by the community of Asia at Ancyra. And if any one transgress any part of what is above decreed, he shall be severely punished. (Josephus, A.J. 16.162-165)
\end{abstract}

Josephus quotes further decrees of Roman officials implementing the one of Augustus in the various cities and provinces of the Empire (Josephus, A.J. 16.166 -173). Josephus names specifically Ephesus, Cyrene, and Sardis. These decrees emphasize not only the legality of the temple tax and prohibit its theft but mention also further antisemitic legal practices. According to them, Jews were forced to appear before a judge on Shabbat (Josephus, A.J. 16.168), were slandered by informants, and were forced to pay additional illegal duties (Josephus, A.J. 16.170). Furthermore, the city of Sardis forbade its Jews to meet and congregate (Josephus, A.J. 16.171). The latter had to weigh particularly heavy, as it also made visiting a synagogue impossible. All in all, the various decrees suggest that Greek legal persecution of Jews was sparked by the issue of the temple tax, but with further legal harassments the various Greek cities went far beyond the prohibition of confiscation of the temple tax.

In the various edicts mentioned by Josephus, the Roman authorities-above all the Emperor-appear as guarantors that enabled the Jews to live according to their religion in the face of Greek legal persecution. At the end of his report about protective legislation for Jews by Roman authorities during the reign of Augustus (A.J. 16.174-176), Josephus emphasizes that he had included the decrees in question as examples convincing the Greeks of his time to refrain from similar persecution. One can thus assume that the decrees of Augustus and his officials had only a limited impact and that the Greek speaking population of the Roman east 
continued to discriminate against Jews by legal and judicial means even until the end of the first century C.E. when Josephus wrote his Antiquities.

Josephus' last remark shows thus that the antisemitic legislations of Greek cities were not isolated events in the Roman Empire. Even a law passed by a Roman Emperor can and should be questioned regarding its antisemitic nature. I am referring to the so-called fiscus Iudaicus.

The revolt against the Roman Empire during the years 66-70 C.E. is called the First Jewish War. This war counts among the most significant crises of Judaism. Its consequences were more than dramatic. At the end of the First Jewish War, Jerusalem and its Temple were destroyed, the Sanhedrin and the Temple cult ceased to exist, tens of thousands of Jews died during the war or were sold into slavery. Given that up to a third of its Jewish population was killed, the demography of Judea shifted significantly in favor of its non-Jewish inhabitants. Of the large religious Jewish groups, only the Pharisees survived. Under the leadership of Yohanan ben Zakkai, they founded a Rabbinic academy at Yavneh. There they began to lay the foundation for a new Jewish existence and identity that was shaped not so much by the Jerusalem Temple cult but by Jewish religious law, that is, the Halakha. The focus of Jewish life shifted inexorably from Judea to the diaspora.

With the destruction of Jerusalem and its Temple, the temple tax came to its end as well. Emperor Vespasian decreed that this tax should now be paid by all Jews to the temple of Jupiter Capitolinus in Rome:

He also laid a tribute upon the Jews wheresoever they were, and enjoined every one of them to bring two drachmae every year into the Capitol, as they used to pay the same to the temple at Jerusalem. (Josephus, B.J. 7.218)

Egyptian papyri show that in comparison to the original temple tax, Vespasian reduced the age from which the tax had to be paid by three years and also included Jewish women and slaves in it. Under these conditions, the two Drachma tax could amount to a huge burden for an average family. For Egypt, tax receipts that survived from antiquity show that the tax for one person was roughly equivalent to the value of five days' wages for a normal worker. This means that a Jewish family had to raise a whole month's income for this special levy that was soon to be known as the "Jewish tax" (fiscus Iudaicus). ${ }^{39}$

39 Cf. E. M. Smallwood, The Jews under Roman Rule: From Pompey to Diocletian: A Study in Political Relations (Leiden: Brill, 1976), 371-74. 
A mention of the fiscus Iudaicus by the church father Origen, who lived in the first half of the third century C.E., shows that this "Jewish tax" existed at least into the third century C.E.:

But you say, How could they who were in captivity pass sentence of death? asserting, I know not on what grounds, that Susanna was the wife of a king, because of the name Joakim. The answer is, that it is no uncommon thing, when great nations become subject, that the king should allow the captives to use their own laws and courts of justice. Now, for instance, that the Romans rule, and the Jews pay the half-shekel to them, how great power by the concession of Cæsar the ethnarch has; so that we, who have had experience of it, know that he differs in little from a true king! (Origen, Ep. Afr., 14) ${ }^{40}$

The fiscus Iudaicus introduced by Vespasian points to an important reason for many legal persecutions of Jews, that is, the financial greed of states and rulers as well as the desire for economic and professional advantages over the Jewish population. Vespasian's law was to find many imitators in medieval and (early) modern times through the Nazi period and had thus a lasting impact on the history of the legal persecution of Jews.

\section{Christian Jew-Hatred in Antiquity}

As argued above, the Jew-hatred among early Christians differed in two ways from the Jew-hatred of ancient pagan religions. On the one hand, the Christian communities of the first three centuries C.E. did not have any state power that would have made legal persecutions or physical persecutions organized by official authorities possible. Early Christians were rather themselves repeatedly victims of persecutions by Romans or even the Roman Empire as a whole. On the other hand, Christianity developed out of Judaism and was thus compelled to construct its own religious group identity in contrast to Judaism. There is hardly a book in the New Testament and hardly an ancient Christian author whose ideas are not shaped by this need for demarcation from Judaism.

The sad reality of this wealth of sources for ancient Christian antisemitism can by no means be dealt with exhaustively in the space of this brief paper. In the following I would like to restrict myself to the discussion of two authors

40 Trans. F. Crombie, Tertullian, Part Fourth; Minucius Felix; Commodian; Origen, Part First and Second, vol. 4 of Ante-Nicene Fathers, ed. A. Roberts, J. Donaldson, and A. Cleveland Coxe (Buffalo, NY: Christian Literature, 1885). 
who I believe are representative for the cultural persecution of the Jews by ancient Christians, Paul of Tarsus and the church father Lactantius.

\subsection{The Jew-Hatred of Paul of Tarsus as Evident in 1 Thess 2:13-16}

The New Testament includes the earliest Christian literature containing passages whose text is antisemitic. ${ }^{41}$ Many parts of the New Testament are more than harsh in their polemics against Jews and Judaism. The Gospel of John, for example, describes the Jews as children of the devil: "You are from your father, the devil, and you choose to do your fathers desire"42 (John 8:44). Luke attacks the Pharisees as money-grubbing: "The Pharisees who were lovers of money heard all this and they ridiculed him” (Luke 16:14). Paul describes his Jewish existence in Phil 3:8 as okú $\beta \alpha \lambda \alpha-$ a word designating excrements-and attacks the Jews in 1 Thess 2:15 as not acceptable to God and as "hostile against all human beings."

The letters that Paul of Tarsus sent to various early Christian communities are among the earliest Christian literature known today. As Paul's letters contain antisemitic slanders and have an antisemitic reception history, they are the earliest Christian literature that is at least in part antisemitic.

But who was Paul? Concerning Paul's life, his letter to the Galatians and the book of Acts contain important information. While Acts was written decades after Paul died, Gal 1:10-24 is autobiographical in character. What is known is that Paul was born into a Jewish family in the Cilician metropolis Tarsus. He was a Roman citizen and by occupation a tent maker. Paul was a member of the Pharisaic movement (Phil 3:5; Acts 23:6; 26:5) and a staunch Jew. In Galatians 1, he describes his Jewish past as follows:

41 For a more detailed argumentation of the following and a discussion with scholarly literature, see A. Lange, "Intra- und extrajüdische Polemiken: Ein Vergleich von Essenern und Urchristen," in The Separation between the Just and the Unjust in Early Judaism and in the Sayings Source/Die Scheidung zwischen Gerechten und Ungerechten in Frühjudentum und Logienquelle, vol. 1 of $Q$ in Context, ed. M. Tiwald (Göttingen: V\&R unipress, 2015), 61-81; and A. Lange, "Inner- and Extra-Jewish Polemics: The Parting of the Ways Once Again," in Sibyls, Scriptures, and Scrolls: John Collins at Seventy, ed. J. Baden, H. Najman, and E. Tigchelaar (Leiden: Brill, 2017), 2:727-46.

42 English translations of New Testament texts are according to the NRSV unless otherwise noted. 
You have heard, no doubt, of my earlier life in Judaism. I was violently persecuting the church of God and was trying to destroy it. I advanced in Judaism beyond many among my people of the same age, for I was far more zealous for the traditions of my ancestors. (Gal 1:13-14)

The book of Acts claims that Paul was educated in Jerusalem by Gamaliel:

I am a Jew, born in Tarsus in Cilicia, but brought up in this city at the feet of Gamaliel, educated strictly according to our ancestral law, being zealous for God, just as all of you are today. I persecuted this Way up to the point of death by binding both men and women and putting them in prison, as the high priest and the whole council of elders can testify about me. From them I also received letters to the brothers in Damascus, and I went there in order to bind those who were there and to bring them back to Jerusalem for punishment. (Acts 22:3-5)

For an unknown period of time after his training, Paul appears to have been charged with the persecution of early Christians. According to his own information, on the way to Damascus, Paul converted to Christianity because of a visionary experience. This conversion event can be dated between the years 31 and 32 C.E. Afterwards, Paul began to missionize the non-Jewish population of Syria. After the apostolic council of 48 C.E., on several long trips, Paul developed active missionary activity mainly in Asia Minor and Greece. Disputes in or conflicts with the Christian communities he founded, Paul tried to solve with the help of letters. Some of these letters (Romans, 1-2 Corinthians, Galatians, Philippians, 1 Thessalonians, and Philemon) are still preserved in the New Testament. Because Paul's letters responded to specific occasions, they do not give a coherent and systematic description of his theology. It is therefore not surprising that Paul articulates his position on Judaism in many different ways emphasizing various facets of his ideas.

The first letter to the Thessalonians is widely regarded as the earliest preserved letter of Paul. Paul founded the Christian community of Thessaloniki most likely in the year 49 C.E. It consisted mainly of gentile Christians. Paul wrote 1 Thessalonians in the year 50 C.E. The letter addresses different questions which the Christians of Thessaloniki asked Paul by way of a letter of their own.

According to the book of Acts, Paul had a conflict with the Jews of Thessaloniki when he founded the Christian community of that city (Acts 17:1-9). Given the sharp polemics against Jews in 1 Thess 2:13-16, it is likely that the report of Acts 17:1-9 goes back to a real conflict between the Christians and Jews of the Thessaloniki. One of the questions of the gentile Christian community of Thessaloniki aimed thus most likely on the significance of Judaism as related to Christianity. This is all the more likely as 1 Thess 2:14 could imply that 
the Christians of Thessaloniki perceived the Jewish community of this city as a threat to their preaching of the gospel:

\begin{abstract}
And because of this we thank God constantly, that when you received the word of God by way of preaching from us you accepted it not as a word of humans but as what it truly is, the word of God, which is having an effect in you as believers. 14 Because you, brothers, became imitators of the churches of God, that are Judea in Christ Jesus, because you as well suffered from same things from your own compatriots as they did also from the Jews

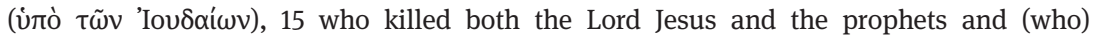

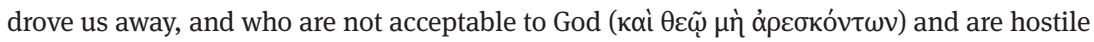

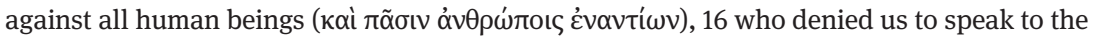
Gentiles that they may be saved, in order to fill up the measure of their sins constantly. But (God's) wrath came over them repeatedly in the end. (1 Thess 2:13-16 ${ }^{43}$
\end{abstract}

Paul gives the reason for this terrible polemic against the Jews in v. 16: "who denied us to speak to the Gentiles that they may be saved." Paul accuses thus the Jews of Thessaloniki to have denied him the preaching of the Christian gospel in their city. First Thessalonians 2:14 suggests that the Jews of Thessaloniki continued to act against the missionary work of the newly founded Christian community after Paul's departure as well.

Out of this situation, Paul constructs in 1 Thess 2:14-16 a principal antithesis between Jews and Christians, Judaism and Christianity.

First Thessalonians 2:15a claims that the Jews would have murdered Jesus and the Prophets and that they persecuted the Christians of Thessaloniki and other cities. First Thessalonians 2:15a is the earliest preserved reference to the Christian deicide slander. The deicide slander is the false accusation that the Jews would have crucified Jesus of Nazareth who is regarded in Christianity as the son of God. This polemic was to develop a devastating reception history and became one of the main antisemitic accusations, Christianity slandered Judaism with. Only the famous declaration Nostra Aetate of the Second Vatican Council officially abolished this slander on October 28, 1965. However, many Christians all over the world are still convinced today that the Jews perceived as a collective would have crucified Jesus. ${ }^{44}$ First Thessalonians 2:15b infers

43 Translation by the author of this article.

44 The Anti-Defamation League included the deicide slander in its antisemitism surveys of the US-American population until the year 2016. In the years 2007 through 2016, between 25 and 31 percent of US-Americans claimed that the Jews were responsible for the execution of Jesus, cf. "A Survey about Attitudes towards Jews in America," Anti-Defamation League, issued October 2016, accessed October 29, 2020, https://www.adl.org/sites/default/files/documents/ADL_MS_Survey_ Pres_1_25_17.pdf, 21. A survey by M. Gottschlich and O. Gruber shows that 8.6 percent of Austria's population similarly holds the Jews responsible for the death of Jesus, cf. M. Gottschlich and O. 
from the deicide slander and the slander that the Jews would have killed the prophets and persecute Christians that they "are not acceptable to God

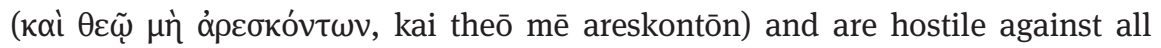

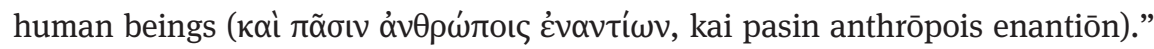
Similar to Greco-Egyptian and Roman antisemitism, Paul describes Judaism here as a negative anti-divine force, which would persecute truly religious peoples in their alleged godlessness and misanthropy. While it remains uncertain if Paul knew the writings of pagan antisemites that are extant today, there can be little doubt that during his Hellenistic education Paul came into contact with Greek antisemitic ideas. Whomever Paul might have read, the influence of GrecoEgyptian antisemitism on his argumentation in 1 Thess 2:15 is difficult to deny. Paul employs the topics of pagan antisemites to slander the Jews of Thessaloniki with his Christian addressees. Paul employs thus in 1 Thess 2:15 a Jewish and a pagan tradition that interpret each other in support of his accusation of Jewish deicide. He uses the pagan antisemitic slander of Jewish godlessness to interpret the Jewish tradition of the murder of the prophets to his pagan audience.

In turn, the Greek gentile readers of Paul's letter had to understand 1 Thess 2:15 in the sense of Greek antisemitic polemics. The slanders of deicide and godlessness had to remind the gentile Christians of Thessaloniki of polemics like Manetho and Apion voiced them. Both authors claimed that Jews would have systematically acted against the religion of Egypt, slaughtering sacred animals of Egypt and destroying its altars. The assertion that the Jews would not please God had to remind the Thessalonians of polemics which connected the Jews with the Greco-Egyptian chaos deity Seth-Typhon. Similarly, the Thessalonians had to associate Paul's accusation that the Jews would be the enemy of all people with accusations of misanthropy by Greek antisemites.

Not only did Paul employ thus in 1 Thess 2:13-16 a traditional pattern of Greek antisemitic thought, he also had to know which antisemitic associations he was evoking with these traditions in the Greek Christians of Thessaloniki.

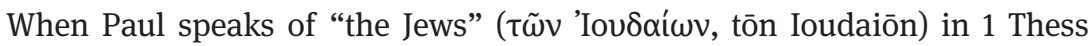
2:14 and contrasts them with the Christians as their persecutors, Paul clearly separates himself and all other Christians from Judaism. The fact that he uses motifs of pagan antisemitism in his polemics against Jews confirms this self-delimitation of Christianity from Judaism and reveals the antisemitic character of the passage. First Thessalonians 2:14-16 does thus not document the conflict of one

Gruber, Waldheims Erbe: Antisemitische Einstellungen der österreichischen Bevölkerung: Ergebnisse einer Repräsentativbefragung 2010/2011, unpublished study, 2011. Results of the Austrian survey are included in M. Gottschlich, Die grosse Abneigung: Wie Antisemitisch ist Österreich? Kritische Befunde zu einer sozialen Krankheit (Wien: Czernin, 2012). 
Jewish group with another one but attests to the polemics of one religious group against another one with the help of traditional antisemitic stereotypes.

Already in the earliest preserved work of Christian literature, Christian identity is thus constructed by way of an antisemitic dissociation from the Jewish parent religion of Christianity. Paul began a long history of antisemitic constructions of Christian and other (religious) group identities that continues as of today and marks one of basic causes of antisemitism. ${ }^{45}$

\subsection{The Jew-Hatred of Lactantius}

While Paul was arguably the first Christian thinker of whom writings are still preserved, Lactantius' work marks the transition from antiquity to late antiquity. Not only did Lactantius experience the last persecution of Christians by the Roman Empire but also how Constantine the Great made Christianity the preferred religion of the Roman state in 313 C.E.

Lactantius' real name was Lucius Caecilius Firmanius. The epithet Lactantius is first attested in the writings of Jerome (De viris illustribus 80). Lactantius was born around 250 C.E. in the Roman province of Africa and died around 320 or 325 C.E. in Trier. He was the official rhetorician for Emperor Diocletian in Nicomedia and resigned from this position after his conversion to Christianity on February 24, 303 C.E. shortly before the Diocletian persecution of Christians. Lactantius later became an advisor to Emperor Constantine and the teacher of his son Crispus, with whom he went to Trier in 317 C.E. The main work of Lactantius is the apology Institutiones Divinae or in English "Divine Institutions," of which he himself has compiled a summary: Epitome divinarum institutionum ("The Epitome of the Divine Institutions"). In the Middle Ages, Lactantius' propagandistic work De mortibus persecutorum ("On the Deaths of the Persecutors") was particularly valued. In this book, Lactantius tells the stories of how ten Roman emperors suffered and died.

Like most patristic authors, Lactantius was convinced of the deicide slander. A brief remark in De mortibus persecutorum 2 shows that for Lactantius the Jewish guilt for the death of Jesus was beyond question:

45 Cf. A. Lange and K. Mayerhofer, "Introduction," in Confronting Antisemitism from the Perspectives of Christianity, Islam, and Judaism, vol. 2 of An End to Antisemitism!, ed. A. Lange et al. (Berlin: De Gruyter, 2019), 13-22; and the introduction in the present volume, 1-27. 
In the latter days of the Emperor Tiberius, in the consulship of Ruberius Geminus and Fufius Geminus, and on the tenth of the kalends in April, as I find it written, Jesus Christ was crucified by the Jews. ${ }^{46}$

In the Epitome of the Divine Institutions (§45), Lactantius can even describe in great detail how the Jews would have killed Jesus because he was hailed as the son of God as would have been foretold in the Wisdom of Solomon 2:12-22. Lactantius claims that not Pilate but the Jewish people and the Jewish authorities captured Jesus and sentenced him to death by crucifixion. Before Jesus' execution, the Jews mocked, beaten, scourged, and tortured Jesus. He further claims that the (Jewish) executioners cast lots over Jesus' tunic and mantle and then crucified him. Lactantius' report in the Epitome of the Divine Institutions is clearly a distorted version of the biblical passion narrative that tries to emphasize the alleged Jewish killing of Jesus even more than the New Testament does.

Already the deicide slander suggests that Lactantius was hostile to Judaism. In line with his antisemitism and in extending the idea of deicide in the seventh book of the Divine Institutions, Lactantius claims that the Jews would await the coming of the Messiah but in vain, as Jesus would bring salvation to the Christian with his second coming but suffering and punishment for the Jews. Both would correspond to all their sins and account for the holy blood they would have shed when murdering the Jesus.

I will now come to the remaining part of the subject, that an end may be put to the work. But this remains, that we should treat of the judgment of God, which will then be established when our Lord shall return to the earth to render to every one either a reward or punishment, according to his desert. Therefore, as we spoke in the fourth book concerning His first advent, so in this book we will relate His second advent, which the Jews also both confess and hope for; but in vain, since He must return to the confusion of those for whose call $\mathrm{He}$ had before come. For they who impiously treated Him with violence in His humiliation, will experience Him in His power as a conqueror; and, God requiting them, they will suffer all those things which they read and do not understand; inasmuch as, being polluted with all sins, and moreover sprinkled with the blood of the Holy One, they were devoted to eternal punishment by that very One on whom they laid wicked hands. But we shall have a separate subject against the Jews, in which we shall convict them of error and guilt. (Divine Institutions 7:1.23-25)

46 All translations of Lactantius' works are according to A. Cleveland Coxe, Lactantius, Venantius, Asterius, Victorinus, Dionysius, Apostolic Teaching and Constitutions, 2 Clement, Early Liturgies, vol. 7 of Ante-Nicene Fathers, ed. A. Roberts, J. Donaldson, and A. Cleveland Coxe (New York: Christian Literature, 1886). 
Lactantius explains in more details what the offenses of the Jews were and what their punishments look like in his Epitome of the Divine Institutions. There, Lactantius describes the history of Judaism as characterized by divine caring for the chosen people and by Jewish rejection of that caring. Similar to Paul, Lactantius uses thus the stereotype of Jewish godlessness to rewrite Jewish history into a history of idolatry and murder of the prophets.

Like pagan antisemites, Lactantius constructs a counter-narrative of the history of Israel. However, in contrast to pagan antisemites, Lactantius' goal is not to destroy the Jewish cultural memory. Like many Christian authors before him, with his counter-narrative, Lactantius wants to appropriate the Jewish cultural memory and turn it into a Christian one. Lactantius does thus not aim at the intertextual destruction of Jewish identity but rather at an intertextual expropriation of the cultural memory by which Jewish cultural identity is constructed.

However, with his history of the Jewish rejection of God, Lactantius wants to achieve even more. He wants to explain to his Christian audience why key passages of the Jewish Holy Scriptures would not foretell salvation for the Jews but would announce Jesus as the Messianic savior of the gentiles. Through Jesus Christ would God have given salvation to the Christians and would have taken it away from the Jews. Christianity would have therefore replaced Judaism in salvation history. This model of thought is called supersessionism or replacement theology and is another classic component of ancient Christian Jew-hatred that unfortunately still shapes the thinking of many Christians up to the present day.

Therefore they served God, being bound by the chains of the law. But they also, by degrees going astray to profane rites, undertook the worship of strange gods, and, leaving the worship of their fathers, sacrificed to senseless images. Therefore God sent to them prophets filled with the Divine Spirit, to upbraid them with their sins and proclaim repentance, to threaten them with the vengeance which would follow, and announce that it would come to pass, if they persisted in the same faults, that He would send another as the bearer of a new law; and having removed the ungrateful people from their inheritance, He would assemble to Himself a more faithful people from foreign nations. But they not only persisted in their course, but even slew the messengers themselves. Therefore He condemned them on account of these deeds: nor did He any longer send messengers to a stubborn people; but He sent His own Son, to call all nations to the favour of God. Nor, however, did He shut them out, impious and ungrateful as they were, from the hope of salvation: but He sent Him to them before all others, that if they should by chance obey, they might not lose that which they had received; but if they should refuse to receive their God, then, the heirs being removed, the Gentiles would come into possession. Therefore the supreme Father ordered Him to descend to the earth, and to put on a human body, that, being subject to the sufferings of the flesh, He might teach virtue and patience not only by words, but also by deeds. Therefore He was born a second time as man, of a virgin, without a father, that, as in His first spiritual birth, being born of God alone, He was made a sacred spirit, so 
in His second and fleshly birth, being born of a mother only, He might become holy flesh, that through Him the flesh, which had become subject to sin, might be freed from destruction. (Epit. 43)

That God would have rejected the Jews and would have freed the gentiles "from the darkness of this present life and from the chains of demons," would leave no doubt about the salvific exclusivity of Christianity which would represent the only way to salvation. An example for this antisemitic argument of Lactantius can be found in Epitome 49 (cf. also Epit. 48).

If therefore the Jews have been rejected by God, as the faith due to the sacred writings shows, and the Gentiles, as we see, brought in, and freed from the darkness of this present life and from the chains of demons, it follows that no other hope is proposed to man, unless he shall follow true religion and true wisdom, which is in Christ, and he who is ignorant of Him is always estranged from the truth and from God.

\section{Conclusions}

My above survey leaves no doubt that Jew-hatred existed antiquity. Whether it was widespread or not does not qualify as an argument to claim that antiquity was free of antisemitism. A low number of antisemitic incidents in a given time period can only imply that Jew-hatred might not have been a mainstream phenomenon but not that it did not exist. Given the incredibly large gap of knowledge all studies of the ancient world suffer from, I would not argue that the source situation for Jew-hatred is any different than for many other phenomena in antiquity. That not much evidence is preserved from antiquity points normally only to the huge amount of ignorance about the ancient world the study of antiquity always suffers from. Furthermore, it must be emphasized that as compared to pagan literature from antiquity, ancient and late ancient Christian literature is an unwelcome treasure trove of Jew-hatred with hardly a Christian author from these periods not polemizing against Jews and Judaism as the parent religion of Christianity.

Whether ancient Jew-hatred qualifies as antisemitism or not is a matter of definition. Those who argue that only racist Jew-hatred is antisemitism will most likely deny the existence of ancient antisemitism. ${ }^{47}$ However, as argued above, this narrow definition of antisemitism, misconceives the heterogenous

47 See e. g. Gruen, “The Blood Libel and the Leper Libel: Ancient Antisemitism?,” in the present volume, 79-99. 
nature of antisemitism itself which cannot easily be limited to one particular form of hatred and intolerance. For this reason, IHRA's working definition of antisemitism is based on a more inclusive understanding of antisemitism that qualifies all forms of Jew-hatred as antisemitism. If the working definition of antisemitism is applied to ancient pagan and ancient Christian texts, the contents of these texts qualify as much as antisemitism as texts of Christian white supremacists in the US or of Islamic extremists do today.

Despite its temporal remoteness, the study of ancient antisemitism is important for many reasons. I hope to have shown above that these three forms of antisemitic persecution existed already in antiquity. Next to legal persecution via regional legislative and judicial measures, and next to physical persecution in various geographical regions, Jews were target by way of cultural persecution in their culture and religion to destroy or appropriate their cultural memory. Both the destruction and appropriation of the Jewish cultural memory would have resulted in a cultural genocide if successful. While ancient attempts at cultural genocide failed, the system of religious symbols that ancient pagan and Christian antisemites created influences the perception of Jews as of today.

An example is 1 Thess 2:13-16 discussed above. In this text, Paul employed the idea of Jewish godlessness from pagan texts to interpret the crucifixion of Jesus as the latest murder in a long line of the Jewish killings of prophets. This is all the more significant as due to his Jewish education, Paul must have known that crucifixion was a Roman but not a Jewish form of capital punishment and that Romans reserved the death penalty in their provinces for their own jurisdiction.

My example of Lactantius shows how Paul's antisemitic interpretation of the crucifixion of Jesus of Nazareth provided not only an antisemitic interpretation of the death of Jesus but created an antisemitic religious tradition of deicide which serves since antiquity as an interpretative key enabling antisemites ever since to read Jews and Judaism as godless murders of the son of God.

An example for how such ancient Christian texts provided and provide interpretative keys that form preconceptions through which even modern Jews and Judaism are interpreted is the statement of an Austro-German politician from the first half of the twentieth century.

However, the latter made no secret of his attitude toward the Jewish people; if necessary he even grabbed a whip to this adversary of humanity out of the temple of the Lord, who as always regarded religion at that time as a means for business. For this, Christ was of course nailed to the Cross, while today's (political) Party-Christianity demeans itself to beg for Jew- 
ish votes during election and later seeks to negotiate backstairs politics with atheistic Jew parties, namely against (their) own nationhood. ${ }^{48}$

The above quote comes out of Hitler's infamous book Mein Kampf. It shows that even Hitler's ideas about Judaism where very much influenced by antisemitic traditions such as the deicide that were created by ancient Christians. While it must remain unclear which ancient source influenced Hitler in his understanding of Jesus' crucifixion as a Jewish murder, it cannot be doubted that Hitler argues not only a (fiscal) world-conspiracy theory but clearly perceives Jews as murders of the son of God.

Next to the impact that ancient antisemitic traditions have on modern antisemitism, there are other ways in which ancient Jew-hatred laid the groundwork for even contemporary antisemitism. For instance, ancient Christianity constructed its own religious group identity in dissociation from its Jewish mother religion. For this purpose, ancient Christians employed pagan traditions of Jewhatred and developed new antisemitic traditions. The construction of antisemitic group identities by way of Jew-hatred is a pattern that can be observed in almost all forms of antisemitism ever since.

Armin Lange is Professor of Second Temple Judaism at the University of Vienna's Department of Jewish Studies as well as a corresponding member of the Austrian Academy of Sciences. His research specializes in ancient Judaism, the Dead Sea Scrolls, the textual criticism of the Hebrew Bible, ancient antisemitism, and the cultural and religious histories of antisemitism. He has published widely in all of these fields.

48 A. Hitler, Hitler, Mein Kampf: Eine Kritische Edition, ed. C. Hartmann, O. Plöckinger, and R. Töppel (München: Institut für Zeitgeschichte, 2016), 1:799: "Freilich machte dieser aus seiner Gesinnung dem jüdischen Volk gegenüber keinen Hehl, griff, wenn nötig, sogar zur Peitsche, um aus dem Tempel des Herrn diesen Widersacher jedes Menschentums zu treiben, der auch damals wie immer in der Religion nur ein Mittel zur geschäftlichen Existenz sah. Dafür wurde dann Christus freilich an das Kreuz geschlagen, während unser heutiges Parteichristentum sich herabwürdigt, bei den Wahlen um jüdische Stimmen zu betteln, und später mit atheistischen Judenparteien politische Schiebungen zu vereinbaren sucht, und zwar gegen das eigene Volkstum.” Translation by the author of this article. 


\section{Bibliography}

\section{Primary Sources}

Bopp, Franz. Ueber das Konjugationssystem der Sanskritsprache in Vergleichung mit jenem der griechischen, lateinischen, persischen und germanischen Sprache. Frankfurt/Main: Windischmann, 1816.

Coxe, A. Cleveland. Lactantius, Venantius, Asterius, Victorinus, Dionysius, Apostolic Teaching and Constitutions, 2 Clement, Early Liturgies, vol. 7 of Ante-Nicene Fathers, edited by Alexander Roberts, James Donaldson, and A. Cleveland Coxe. New York: Christian Literature, 1886.

Flavius Josephus. Against Apion: Translation and Commentary. Translated by John M. G. Barclay. Leiden: Brill, 2007.

Flavius Josephus. The New Complete Works of Josephus. Translated by William Whiston. Grand Rapids: Kregel, 1999.

Hess, Rudolph. “An die Ausländer guten Willens.” In Reden, 99-119. München: Zentralverlag der NSDAP, Franz Eher Nachf., 1938.

Hitler, Adolf. Hitler, Mein Kampf: Eine Kritische Edition. Edited by Christian Hartmann, Othmar Plöckinger, and Roman Töppel. 2 vols. München: Institut für Zeitgeschichte, 2016.

Lassen, Christian. Indische Altertumskunde. 4 vols. Bonn: H. B. König, 1847-1861.

Lemkin, Raphael. Axis Rule in Occupied Europe: Laws of Occupation, Analysis of Government, Proposals for Redress. Washington: Carnegie Endowment for International Peace Division of International Law, 1944.

Marr, Wilhelm. "Antisemitische Wucht und Verluste." Österreichischer Volksfreund, 1891.

Marr, Wilhelm. Der Sieg des Judenthums über das Germanenthum: Vom nicht confessionellen Standpunkt aus betrachtet: Vae Victis! Bern: Rudolph Costenoble, 1879.

Origen. "Letter to Africanus." In Tertullian, Part Fourth; Minucius Felix; Commodian; Origen, Part First and Second. Translated by Frederick Crombie. Vol. 4 of Ante-Nicene Fathers, edited by Alexander Roberts, James Donaldson, and A. Cleveland Coxe. Buffalo: Christian Literature, 1885.

Philo of Alexandria. On the Embassy to Gaius. General Indexes. Translated by F. H. Colson, index by J. W. Earp. Loeb Classical Library 379. Cambridge: Harvard University Press, 1962.

Philo of Alexandria. Philo's Flaccus: The First Pogrom: Introduction, Translation, and Commentary, by Pieter Willem van der Horst. Leiden: Brill, 2003.

Renan, Ernest. Études d'histoire religieuse. Paris: Lévy, 1880.

Schlözer, August Ludwig. "Von den Chaldäern." Repertorium fuer biblische und morgenlaendische Literatur 8 (1781): 113-76.

Steinschneider, Moritz. Review of "Zur Charakteristik der semitischen Völker" by Heymann Steinthal. Hamaskir: Hebräische Bibliographie: Blätter für neuere und ältere Literatur des Judenthums 3 (1860): 16.

Steinthal, Heymann. Über Juden und Judenthum: Vorträge und Aufsätze. Edited by Gustav Karpeles. Berlin: Poppelauer, 1906.

Steinthal, Heymann. "Zur Charakteristik der semitischen Völker." Zeitschrift für Völkerpsychologie und Sprachwissenschaft 1 (1860): 328-45. 


\section{Secondary Sources}

American Jewish Committee. "AJC Survey of American Jews on Antisemitism in America." Issued October 2019. Accessed October 28, 2020. https://www.ajc.org/sites/default/ files/pdf/2019-11/2019AntisemitismSurvey-Book_11.19.pdf.

Anti-Defamation League. "A Survey about Attitudes towards Jews in America." Issued October 2016. Accessed October 29, 2020. https://www.adl.org/sites/default/files/documents/ ADL_MS_Survey_Pres_1_25_17.pdf.

Bar-Kochva, Bezalel. The Image of the Jews in Greek Literature: The Hellenistic Period. Berkeley: University of California Press, 2010.

Beller, Steven. Antisemitism: A Very Short Introduction. Oxford: Oxford University Press, 2007. Berger, David, ed. History and Hate: The Dimensions of Anti-Semitism. Philadelphia: Jewish Publication Society, 1997.

Bergmann, Werner. "Pogrom.” In Begriffe, Theorien, Ideologien, vol. 3 of Handbuch des Antisemitismus, edited by Wolfgang Benz, 269-70. Berlin: De Gruyter, 2010.

Bergmann, Werner. "Pogrome.” In Internationales Handbuch der Gewaltforschung, edited by Wilhelm Heitmeyer and John Hagan, 441-60. Wiesbaden: Westdeutscher Verlag, 2002.

Bergmann, Werner. "Pogrome: Eine spezifische Form kollektiver Gewalt.” Kölner Zeitschrift für Soziologie und Sozialpsychologie 50 (1998): 644-65.

Bilsky, Leora, and Rachel Klagsbrun. "The Return of Cultural Genocide?” European Journal of International Law 29, no. 2 (2018): 373-96.

Chazan, Robert. Medieval Stereotypes and Modern Antisemitism. Berkeley: University of California Press, 1997.

Cuffari, Anton. Judenfeindschaft in Antike und Altem Testament: Terminologische, Historische und Theologische Untersuchungen. Hamburg: Philo, 2007.

Davidson, Lawrence. Cultural Genocide. Brunswick: Rutgers University Press, 2012.

Eriksen, Trond Berg, Håkon Harket, and Einhart Lorenz. Judenhass: Die Geschichte des Antisemitismus von der Antike bis zur Gegenwart. Göttingen: Vandenhoeck \& Ruprecht, 2019.

Gager, John G. The Origins of Anti-Semitism: Attitudes Toward Judaism in Pagan and Christian Antiquity. New York: Oxford University Press, 1985.

Gottschlich, Maximilian. Die grosse Abneigung: Wie Antisemitisch ist Österreich? Kritische Befunde zu einer sozialen Krankheit. Wien: Czernin, 2012.

Gottschlich, Maximilian, and Oliver Gruber. Waldheims Erbe: Antisemitische Einstellungen der österreichischen Bevölkerung: Ergebnisse einer Repräsentativbefragung 2010/2011. Unpublished study, 2011.

Gruen, Erich. "The Blood Libel and the Leper Libel: Ancient Antisemitism?" In Comprehending Antisemitism through the Ages: A Historical Perspective, vol. 3 of An End to Antisemitism!, ed. A. Lange, K. Mayerhofer, D. Porat, and L. H. Schiffman, 79-99. Berlin: De Gruyter, 2021.

Grunfeld, Frederic V. "Cultural Persecution: The First Step Towards Genocide." The UNESCO Courier: A Window Open on the World 38 (1985): 6-7.

Heil, Johannes. “'Antijudaismus' und 'Antisemitismus': Begriffe als Bedeutungsträger.” Jahrbuch für Antisemitismusforschung 6 (1997): 92-114.

Herholt, Volker. Antisemitismus in der Antike: Kontinuitäten und Brüche eines historischen Phänomens. Gutenberg: Computus, 2009. 
International Holocaust Remembrance Alliance. "Working Definition of Antisemitism." Issued July 19, 2018. Accessed October 29, 2020. https://www.holocaustremembrance.com/ sites/default/files/press_release_document_antisemitism.pdf.

Isaac, Benjamin. The Invention of Racism in Classical Antiquity. Princeton: Princeton University Press, 2013.

Lange, Armin. "Inner- and Extra-Jewish Polemics: The Parting of the Ways Once Again." In Sibyls, Scriptures, and Scrolls: John Collins at Seventy, edited by Joel Baden, Hindy Najman, and Eibert Tigchelaar, 2:727-46. Leiden: Brill, 2017.

Lange, Armin. "Intra- und extrajüdische Polemiken: Ein Vergleich von Essenern und Urchristen." In The Separation between the Just and the Unjust in Early Judaism and in the Sayings Source/Die Scheidung zwischen Gerechten und Ungerechten in Frühjudentum und Logienquelle, vol. 1 of $Q$ in Context, edited by Markus Tiwald, 61-81. Göttingen: V\&R unipress, 2015.

Lange, Armin. "The Religious Nature of Antisemitism: The Examples of the Pittsburgh and Poway Shooters." In Europäische Werte, Rechtsstaat, Sicherheit (forthcoming).

Lange, Armin, and Maxine Grossman. "Jews and Judaism between Bedevilment and Source of Salvation: Christianity as a Cause of and Cure against Antisemitism." In Comprehending and Confronting Antisemitism: A Multi-Faceted Approach, vol. 1 of An End to Antisemitism!, edited by A. Lange, K. Mayerhofer, D. Porat, and L. H. Schiffman, 133-64. Berlin: De Gruyter, 2019.

Langmuir, Gavin I. Toward a Definition of Antisemitism. Berkeley: University of California Press, 1990.

Laquer, Walter. The Changing Face of Anti-Semitism: From Ancient Times to the Present Day. Cary: Oxford University Press, 2006.

Modrzejewski, Joseph Mélèze. The Jews of Egypt: From Rameses II to Emperor Hadrian. Translated by Robert Cornman. Princeton: Princeton University Press, 1997.

Moore, R. I. The Formation of a Persecuting Society: Power and Deviance in Western Europe, 950-1250. Oxford: Blackwell, 1987.

Nicosia, Francis R. Zionism and Anti-Semitism in Nazi Germany. Cambridge: Cambridge University Press, 2008.

Noethlichs, Karl Leo. Die Juden im christlichen Imperium Romanum (4.-6. Jahrhundert). Berlin: Akademie-Verlag, 2001.

Novic, Elisa. The Concept of Cultural Genocide: An International Law Perspective. Oxford: Oxford University Press, 2016.

Perry, Marvin, and Frederick M. Schweitzer. Antisemitism: Myth and Hate from Antiquity to the Present. Basingstoke: Palgrave McMillan, 2005.

Poliakov, Léon. The History of Anti-Semitism. 4 vols. Philadelphia: University of Pennsylvania Press, 2003.

Porat, Dina. "The Working Definition of Antisemitism: A 2018 Perception." In Comprehending and Confronting Antisemitism: A Multi-Faceted Approach, vol. 1 of An End to Antisemitism!, edited by A. Lange, K. Mayerhofer, D. Porat, and L. H. Schiffman, 475-87. Berlin: De Gruyter, 2019.

Quigley, John B. The Genocide Convention: An International Law Analysis. Hampshire: Ashgate, 2006.

Schäfer, Peter. Judeophobia: Attitudes toward the Jews in the Ancient World. Cambridge: Harvard University Press, 1997. 
Schreckenberg, Heinz. Die christlichen Adversus-Judaeos-Texte und ihr literarisches und historisches Umfeld. 3 vols. Frankfurt/Main: Peter Lang, 1982-1994.

Simon, Marcel. Verus Israel: A Study of the Relations between Christians and Jews in the Roman Empire (AD 135-425). Translated by H. McKeating. Oxford: Oxford University Press, 1986.

Smallwood, E. Mary. The Jews under Roman Rule: From Pompey to Diocletian: A Study in Political Relations. Leiden: Brill, 1976.

Thiede, Carsten-Peter, and Urs Stingelin. Die Wurzeln des Antisemitismus: Judenfeindschaft in der Antike, im frühen Christentum und im Koran. Basel: Brunnen-Verlag, 2002.

United Nations. "Convention on the Prevention and Punishment of the Crime of Genocide." Issued December 9, 1948. Accessed November 2, 2020. https://www.un.org/en/genocide prevention/documents/atrocity-crimes/Doc.1_Convention\%20on\%20the $\% 20$ Prevention\% 20and\%20Punishment\%20of\%20the\%20Crime\%20of\%20Genocide.pdf.

Weitzman, Mark. "The IHRA Working Definition of Antisemitism." In Comprehending and Confronting Antisemitism: A Multi-Faceted Approach, vol. 1 of An End to Antisemitism!, edited by A. Lange, K. Mayerhofer, D. Porat, and L. H. Schiffman, 463-73. Berlin: De Gruyter, 2019.

Wistrich, Robert S. Antisemitism: The Longest Hatred. New York: Pantheon, 1992.

Wistrich, Robert S. A Lethal Obsession: Anti-Semitism from Antiquity to the Global Jihad. New York: Random House, 2010.

Yavetz, Zvi. Judenfeindschaft in der Antike: Die Münchener Vorträge. München: Beck, 1997.

Zimmermann, Moshe. "Aufkommen und Diskreditierung des Begriffes Antisemitismus." In Ideologie-Herrschaftssystem-Wirkung in Europa: Festschrift für Werner Jochmann zum 65. Geburtstag, vol. 1 of Das Unrechtsregime: Internationale Forschung über den Nationalsozialismus, edited by Ursula Büttner, 59-77. Hamburg: Hans Christians Verlag, 1986.

Zimmermann, Moshe. Wilhelm Marr: The Patriarch of Anti-Semitism. Oxford: Oxford University Press, 1986. 